\title{
Attenuation of Proinflammatory Responses by $S$-[6]-Gingerol via Inhibition of ROS/NF-Kappa B/COX2 Activation in HuH7 Cells
}

\author{
Xiao-Hong Li, ${ }^{1,2,3}$ Kristine C. Y. McGrath, ${ }^{1,4}$ Van H. Tran, ${ }^{2}$ Yi-Ming Li, \\ Colin C. Duke, ${ }^{2}$ Basil D. Roufogalis, ${ }^{2}$ and Alison K. Heather ${ }^{1,4}$ \\ ${ }^{1}$ Heart Research Institute, Newtown, NSW 2042, Australia \\ ${ }^{2}$ Faculty of Pharmacy, University of Sydney, Camperdown, NSW 2006, Australia \\ ${ }^{3}$ Department of Endocrinology, Dezhou People's Hospital, Dezhou, Shandong 253014, China \\ ${ }^{4}$ School of Medical and Molecular Biosciences, University of Technology, P.O. Box 123, Ultimo, NSW 2007, Australia
}

Correspondence should be addressed to Alison K. Heather; alison.heather@uts.edu.au

Received 14 February 2013; Revised 17 May 2013; Accepted 24 May 2013

Academic Editor: Ke Ren

Copyright (C) 2013 Xiao-Hong Li et al. This is an open access article distributed under the Creative Commons Attribution License, which permits unrestricted use, distribution, and reproduction in any medium, provided the original work is properly cited.

\begin{abstract}
Introduction. Hepatic inflammation underlies the pathogenesis of chronic diseases such as insulin resistance and type 2 diabetes mellitus. S-[6]-Gingerol has been shown to have anti-inflammatory properties. Important inflammatory mediators of interleukins include nuclear factor $\kappa \mathrm{B}(\mathrm{NF} \kappa \mathrm{B})$ and cyclooxygenase 2 (COX2). We now explore the mechanism of anti-inflammatory effects of $S$ [6]-gingerol in liver cells. Methods. HuH7 cells were stimulated with IL1 $\beta$ to establish an in vitro hepatic inflammatory model. Results. S-[6]-Gingerol attenuated IL1 $\beta$-induced inflammation and oxidative stress in $\mathrm{HuH7}$ cells, as evidenced by decreasing mRNA levels of inflammatory factor IL6, IL8, and SAA1, suppression of ROS generation, and increasing mRNA levels of DHCR24. In addition, $S$-[6]-gingerol reduced IL1 $\beta$-induced COX2 upregulation as well as NFא B activity. Similar to the protective effects of $S$ [6]-gingerol, both NS-398 (a selective COX2 inhibitor) and PDTC (a selective NFאB inhibitor) suppressed mRNA levels of IL6, IL8, and SAA1. Importantly, PDTC attenuated IL1 $\beta$-induced overexpression of COX2. Of particular note, the protective effect of $S$-[6]gingerol against the IL1 $\beta$-induced inflammatory response was similar to that of BHT, an ROS scavenger. Conclusions. The findings of this study demonstrate that $S$-[6]-gingerol protects $\mathrm{HuH7}$ cells against IL1 $\beta$-induced inflammatory insults through inhibition of the $\mathrm{ROS} / \mathrm{NF} \kappa \mathrm{B} / \mathrm{COX} 2$ pathway.
\end{abstract}

\section{Introduction}

Hepatic inflammation underlies the pathogenesis of chronic diseases such as insulin resistance, type 2 diabetes mellitus, atherosclerosis, and nonalcoholic fatty liver disease (NAFLD) $[1,2]$. Liver inflammation leads to the secretion of proinflammatory cytokines and chemokines which, in turn, contribute to a feed-forward amplification of the inflammatory signal and subsequent progression of these chronic diseases [3]. Nuclear factor kappa B $(\mathrm{NF} \kappa \mathrm{B})$ is the master regulator of the hepatic inflammatory response. Under basal conditions, $\mathrm{NF} \kappa \mathrm{B}$ is present in the cytoplasm of hepatocytes in a latent form. Upon exposure to proinflammatory stimuli, $\mathrm{NF} \kappa \mathrm{B}$ is activated and migrates to the cell nucleus where it directs transcription of target genes [4]. These include genes encoding cytokines, chemokines, and the enzyme cyclooxygenase
2 (COX2) [5]. Cyclooxygenase (COX) is among the most important proinflammatory mediators and COX2 is responsible for persistent inflammation [6].

Ginger has been known for centuries as a valuable medicinal herb having anti-inflammatory properties $[7,8]$. Different studies have shown that ginger extracts suppress inflammation through inhibition of the classical $\mathrm{NF} \kappa \mathrm{B}$ pathway in various cell types and tissues $[9,10]$. We have recently shown that Zingiber officinale suppressed hepatic $\mathrm{NF} \kappa \mathrm{B}$ activation thereby suppressing cytokine expression from the liver [11]. Phenolic gingerols and related compounds, which are responsible for the pungent taste of ginger, have been a major focus of research related to the anti-inflammatory effects of ginger. S-[6]-Gingerol (1-[4'-hydroxy-3' -methoxyphenyl]-5hydroxy-3-decanone) is the major pungent principle of ginger, with numerous pharmacological properties including 
anti-inflammatory and antioxidant properties [12-14]. However, the mechanisms that underlie the anti-inflammatory effects of S-[6]-gingerol in cytokine-stimulated hepatocytes remain largely unknown.

In the present study, we investigated the anti-inflammatory properties of $S$-[6]-gingerol in $\mathrm{HuH} 7$ cells stimulated by the cytokine, IL1 $\beta$. Our findings show that $S$-[6]-gingerol protects $\mathrm{HuH} 7$ cells against an IL1 $\beta$-induced inflammatory response by inhibiting the reactive-oxygen-species- (ROS-) activated $\mathrm{NF} \kappa \mathrm{B} / \mathrm{COX} 2$ pathway.

\section{Materials and Methods}

2.1. Materials and Cell Culture. [6]-S-Gingerol (1-[4'-hydroxy-3'-methoxyphenyl]-5-hydroxy-3-decanone) was isolated from total ginger extract as described previously [15]. IL1 $\beta$ was purchased from Bio-Scientific Pty. Ltd. (Gymea, NSW, Australia). N-(2-Cyclohexyloxy-4-nitrophenyl)-methane sulfonamide (NS-398), pyrrolidine dithiocarbamate (PDTC), nitroblue tetrazolium (NBT), and butylated hydroxytoluene (BHT) were purchased from Sigma-Aldrich Pty. Ltd (Castle Hill, NSW, Australia). Human hepatocyte HuH7 cells (Health Science Research Resources Bank, Osaka, Japan) were cultured in DMEM medium (Sigma-Aldrich, Castle Hill, NSW, Australia) with 10\% FBS (Invitrogen, Kilsyth, Victoria, Australia) at $37^{\circ} \mathrm{C}$ in $5 \% \mathrm{CO}_{2}$.

2.2. CellTiter-Blue Cell Viability Assay. HuH-7 cells were seeded in 96-well plate in $100 \mu \mathrm{L}$ cell culture media and incubated for 24 hours with $S$-[6]-gingerol $(50 \mu \mathrm{M}, 100 \mu \mathrm{M}$, and $200 \mu \mathrm{M}$ ) or DMSO (vehicle control). Following incubation, $20 \mu \mathrm{L}$ of CellTiter-Blue Reagent (Promega, Madison, USA) was added to each well with shaking for $10 \mathrm{sec}$. After incubation for another 2 hours, the plate was shaken for $10 \mathrm{sec}$ and the fluorescence was recorded at $560 \mathrm{~nm}$ and $590 \mathrm{~nm}$, respectively, according to the manufacture's protocol.

\subsection{Transient Cell Transfections and Luciferase Measurements.} $\mathrm{HuH7}$ cells were transfected using Effectene (Qiagen, Hilden, Germany) with $\mathrm{NF} \kappa \mathrm{B}$-luciferase reporter vector and $\mathrm{pRL}$ TK for transfection control (Promega Corporation, Madison, WI, USA), as previously described [16]. The transfected cells were preincubated with $S$-[6]-gingerol for $6 \mathrm{~h}$ then stimulated with IL1 $\beta$ for $3 \mathrm{~h}$. Luciferase and Renilla activities were detected by assaying cell lysates using the Dual-Luciferase Reporter System (Promega), according to the manufacturer's protocol.

2.4. RT-qPCR. Total RNA was extracted from HuH7 cells using TRI reagent (Sigma-Aldrich), and the concentration was normalized to $100 \mathrm{ng} / \mu \mathrm{L}$ using Nanoveu (LifeScience). cDNA was generated from $100 \mathrm{ng}$ of total RNA using iSCRIPT (BioRad, Regents Park, NSW, Australia). An aliquot of each cDNA sample $(1 \mu \mathrm{L})$ was amplified by real-time PCR in reaction mixtures containing primers (12 pmol each) and iQ SYBR Green Supermix (BioRad). Sequences of the primers used in the real-time PCR reaction were as follows: human IL-6 forward: $5^{\prime}$-CAA ATT CGG TAC ATC CTC GAC GGC, reverse: $5^{\prime}$-GGT TCA GGT TGT TTT CTG CCA GTG C; human IL-8 forward: $5^{\prime}$-CGG AAG GAA CCA TCT CAC TGT, reverse: $5^{\prime}$-GGT CCA CTC TCA ATC ACT CTC A; human SAA1 forward: $5^{\prime}$-CCA ATC ACT TCC GAC CTG CTG, reverse: $5^{\prime}$-GCT TTG TAT CCC TGC CCT GAG; human $\beta 2$-microglobulin (B2M) forward: $5^{\prime}$-CAT CCA GCG TAC TCC AAA GA, reverse: $5^{\prime}$-GAC AAG TCT GAA TGC TCC AC. DHCR24 PCR primers were purchased from Qiagen Pty Ltd (Doncaster, VIC, Australia). Amplification was performed in a BioRad iQ5 thermocycler (BioRad) using the following protocol: $95^{\circ} \mathrm{C}$ for $30 \mathrm{sec}, T_{m}$ of specific primer sets for $30 \mathrm{sec}$, and $72^{\circ} \mathrm{C}$ for $30 \mathrm{sec}$. Relative changes in mRNA levels were determined by the $\Delta \Delta \mathrm{CT}$ method [17], using human $\mathrm{B} 2 \mathrm{M}$ as the reference gene.

2.5. Measurement of Intracellular ROS Generation. NBT reduction assay was used to measure intracellular superoxide anion. HuH7 cells were seeded in 12-well plates. After treatment, cells were washed with Hanks balanced salt solution (HBSS, Sigma-Aldrich) and then incubated in Krebs-Henseleit buffer (Sigma-Aldrich) containing $1 \mathrm{mg} / \mathrm{mL}$ NBT for $1 \mathrm{~h}$ at $37^{\circ} \mathrm{C}$. Cells were then washed with HBSS and lysed with phosphate buffer $(80 \mathrm{mM}, \mathrm{pH} 7.8)$ containing sodium dodecyl sulfate (SDS) and gelatin. The cell lysate was centrifuged for $5 \mathrm{~min}$ at $13,000 \times \mathrm{g}$ and the absorbance measured at $540 \mathrm{~nm}$ (formazan) and $450 \mathrm{~nm}$. The relative concentration of superoxide anion was calculated based on the amount of formazan formed according to the standard curve.

2.6. Statistical Analysis. Data are expressed as mean \pm SEM. Differences between two different conditions were determined by one-way ANOVA with Bonferroni's posttest analysis used to determine significance. GraphPad PRISM Software Version 4.03 (GraphPad Software, Inc., San Diego, CA) was used for analyses. Significance was set at $P<0.05$.

\section{Results}

3.1. Cell Viability. To determine if S-[6]-gingerol affected cell viability at the concentration used in the study, cell viability assays were performed. HuH-7 cells were treated with $50 \mu \mathrm{M}$, $100 \mu \mathrm{M}$, or $200 \mu \mathrm{M} S$-[6]-gingerol for 24 hours, and cell viability was determined using the CellTiter-Blue cell viability assay. Figure 1 demonstrated that up to $100 \mu \mathrm{M}$ S-[6]-gingerol did not have a cytotoxic effect for 24 hours with a $6.88 \pm 1.06 \%$ decrease in cell viability compared to DMSO vehicle control $(P>0.05)$.

3.2. S-[6]-Gingerol Suppresses IL1 $\beta$-Induced Inflammatory Cytokine Expression in $\mathrm{HuH7} \mathrm{Cells.} \mathrm{To} \mathrm{investigate} \mathrm{the} \mathrm{effect}$ of $S$-[6]-gingerol on IL1 $\beta$-induced inflammation, mRNA levels of cytokines IL6, IL8, and SAA1 were determined by realtime PCR. After exposure of HuH7 cells to $8 \mathrm{ng} / \mathrm{mL} \mathrm{IL1} \beta$ for $3 \mathrm{~h}$, mRNA levels of IL6 (Figure 2(a)), IL8 (Figure 2(b)), and SAA1 (Figure 2(c)) were significantly increased. Pretreatment with $100 \mu \mathrm{M} S$-[6]-gingerol for $6 \mathrm{~h}$ before exposure to IL1 $\beta$ markedly suppressed IL6 (Figure 2(a)), IL8 (Figure 2(b)), 


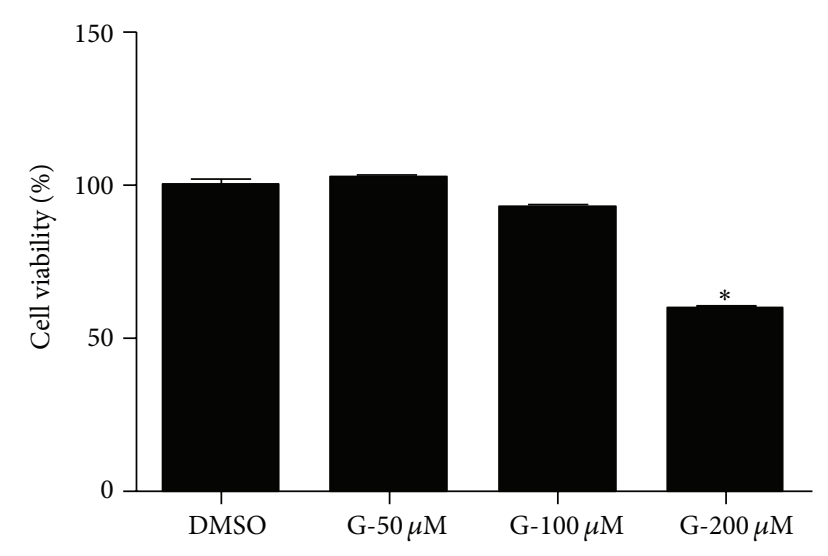

FIgURE 1: $100 \mu \mathrm{M}$ S-[6]-gingerol is not toxic to HuH-7 cells. HuH-7 cells were exposed to $S$-[6]-gingerol $(G)$ at different concentrations $(50 \mu \mathrm{M}, 100 \mu \mathrm{M}$, and $200 \mu \mathrm{M})$ for 24 hours, and cell viability was determined using the CellTiter-Blue cell viability assay. Results are expressed as mean \pm SEM of 3 independent experiments, relative to DMSO vehicle control. ${ }^{*} P<0.05$ versus DMSO vehicle control.

and SAA1 (Figure 2(c)) mRNA levels in HuH7 cells, respectively. These results suggest that $S$-[6]-gingerol has an antiinflammatory effect in IL1 $\beta$-stimulated HuH7 cells.

\subsection{S-[6]-Gingerol Inhibits IL1 $\beta$-Induced Oxidative Stress in} $\mathrm{HuH7}$ Cells. To determine the effect of $S$-[6]-gingerol on IL1 $\beta$-induced oxidative stress, intracellular superoxide and DHCR24 levels were measured. Exposure of HuH7 cells to $8 \mathrm{ng} / \mathrm{mL} \mathrm{IL1} \beta$ for $3 \mathrm{~h}$ led to a noticeable increase in superoxide generation (Figure 3(a)). Pretreatment with $100 \mu \mathrm{M} S$-[6]gingerol for $6 \mathrm{~h}$ prior to IL1 $\beta$ exposure decreased intracellular superoxide levels in $\mathrm{HuH} 7$ cells. Additionally, treatment of $\mathrm{HuH} 7$ cells with $8 \mathrm{ng} / \mathrm{mL}$ IL1 $\beta$ for $3 \mathrm{~h}$ significantly decreased DHCR24 mRNA levels (Figure 3(b)), indicating that IL1 $\beta$ treatment impairs cellular defense mechanisms. Importantly, pretreatment with $100 \mu \mathrm{M} \mathrm{S}$-[6]-gingerol attenuated the inhibitory effect of IL1 $\beta$ on DHCR24 levels in $\mathrm{HuH7}$ cell. These findings suggest that $S$-[6]-gingerol exerts an antioxidative effect on IL1 $\beta$-stimulated $\mathrm{HuH} 7$ cells.

3.4. Downregulation of Induced COX2 Contributes to the AntiInflammatory Effects of S-[6]-Gingerol in IL1 $\beta$-Stimulated $\mathrm{HuH7}$ Cells. After treatment of HuH7 cells with $8 \mathrm{ng} / \mathrm{mL}$ IL1 $\beta$ for $3 \mathrm{~h}$, expression of COX 2 was significantly increased. Pretreatment with $100 \mu \mathrm{M} \mathrm{S}$-[6]-gingerol for $6 \mathrm{~h}$ attenuated the upregulation of COX2 mRNA levels induced by IL1 $\beta$ (Figure 4(a)). Furthermore, pretreatment with $100 \mu \mathrm{M}$ NS398 , a selective inhibitor of COX2, for $30 \mathrm{~min}$ before exposure to IL1 $\beta$ also inhibited mRNA levels of IL6, IL8, and SAA1 (Figure 5). These findings suggest that inhibition of IL1 $\beta$ induced COX2 expression is involved in the protective effect of $\mathrm{S}$-[6]-gingerol in $\mathrm{HuH7}$ cells.

3.5. S-[6]-Gingerol Inhibits IL1 $\beta$-Induced NFאB Activation in $\mathrm{HuH7}$ Cells. Exposure of $\mathrm{HuH7}$ cells to $8 \mathrm{ng} / \mathrm{mL}$ IL1 $\beta$ for $3 \mathrm{~h}$ significantly enhanced $\mathrm{NF} \kappa \mathrm{B}$ activity (Figure $4(\mathrm{~b})$ ). Pretreatment of $\mathrm{HuH7}$ cells with $S$-[6]-gingerol for $6 \mathrm{~h}$ significantly inhibited IL1 $\beta$-induced NFKB activity. In keeping with this result, pretreatment with $50 \mu \mathrm{M}$ PDTC, a selective inhibitor of $\mathrm{NF} \kappa \mathrm{B}$, for $30 \mathrm{~min}$ before exposure to IL1 $\beta$ abrogated IL1 $\beta$ induced COX2, IL6, IL8, and SAA1 expression (Figures 6(a) and 5). Together, these results suggest that the protective effects of $S$-[6]-gingerol against IL1 $\beta$-induced inflammation are, at least in part, associated with inhibition of $\mathrm{NF} \kappa \mathrm{B}$ activation in $\mathrm{HuH7}$ cells.

3.6. Inhibition of Oxidative Stress Is Involved in the Protection of S-[6]-Gingerol against Inflammation in IL1ß-Stimulated $\mathrm{HuH7}$ Cells. Decreasing oxidative stress underlies antiinflammatory effects [18]. We therefore next compared the effect of BHT, an ROS scavenger, with $S$-[6]-gingerol in their ability to suppress IL1 $\beta$-induced IL6, IL8, and SAA1 expression. As expected BHT did decrease mRNA levels of IL6, IL8, and SAA1, and we found that S-[6]-gingerol was equally effective (Figure 5). Furthermore, it was shown that similar to $S$-[6]-gingerol, pretreatment with $50 \mu \mathrm{M}$ BHT inhibited IL1 $\beta$-induced COX2 upregulation (Figure 6(a)) and $\mathrm{NF} \kappa \mathrm{B}$ activity (Figure 6(b)) in HuH7 cells. The previous results indicate that suppressed ROS levels may contribute to the protective effects of $S$-[6]-gingerol against the IL1 $\beta$ induced inflammatory response in $\mathrm{HuH7}$ cells.

\section{Discussion}

The present study demonstrates that $S$-[6]-gingerol has the potential to protect hepatocytes against IL1 $\beta$-induced inflammatory response. Moreover, for the first time, we show that $S$-[6]-gingerol achieves its potent anti-inflammatory effects through inhibition of an ROS-activated NF $\kappa \mathrm{B} / \mathrm{COX} 2$ pathway. These results may explain how ginger improved insulin resistance in high-fat diet rat in our previous study [11].

COX2 has an important role in the inflammatory process. There is extensive evidence based on in vivo and in vitro models of inflammation that COX2 and COX2-induced production of prostaglandins (PGs) are involved in inflammation. Animal models of inflammation have demonstrated that an increase in COX2 mRNA and protein, as well as PG levels, parallels the inflammatory process [19]. COX2 specific inhibitors and monoclonal antibody to prostaglandin E2 (PGE2) have been shown to control inflammation [20, 21]. A study on chronic liver disease has shown that endoplasmic reticulum stress induced by hepatitis $B$ virus $\mathrm{X}$ protein $(\mathrm{HBx})$ enhanced COX2 expression in $\mathrm{HBx}$ transgenic mice and in the $\mathrm{HuH} 7$ cells that were transfected with $\mathrm{HBx}$ expression plasmid [22]. COX2 is usually absent under basal conditions, but it is inducible by various cytokines, growth factors, and mitogens [23-26]. It has been shown that the inducible COX2 is not only responsible for production of PGs in response to inflammation [24, 25], but also a potent proinflammatory mediator that promotes the production of proinflammatory cytokines including IL6 and IL1 $\beta$ [27]. Treatment with a selective COX2 inhibitor blocks the secretion of proinflammatory cytokines IL6, IL1 $\beta$, and IL8 induced 


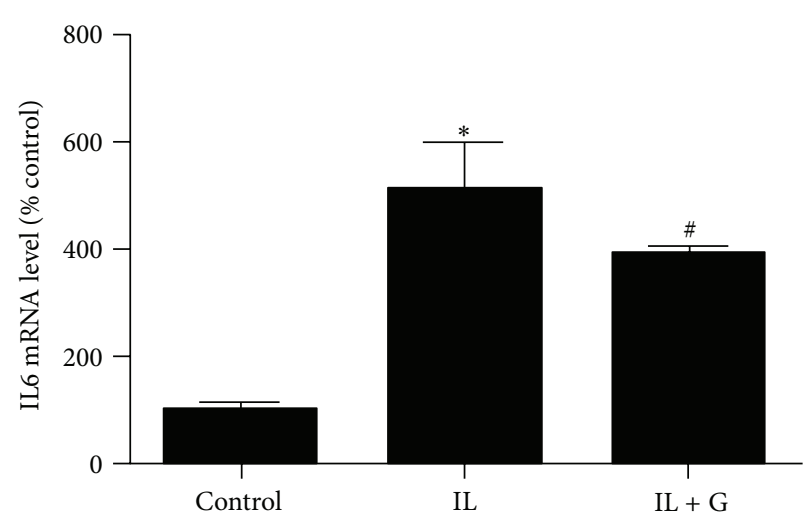

(a)

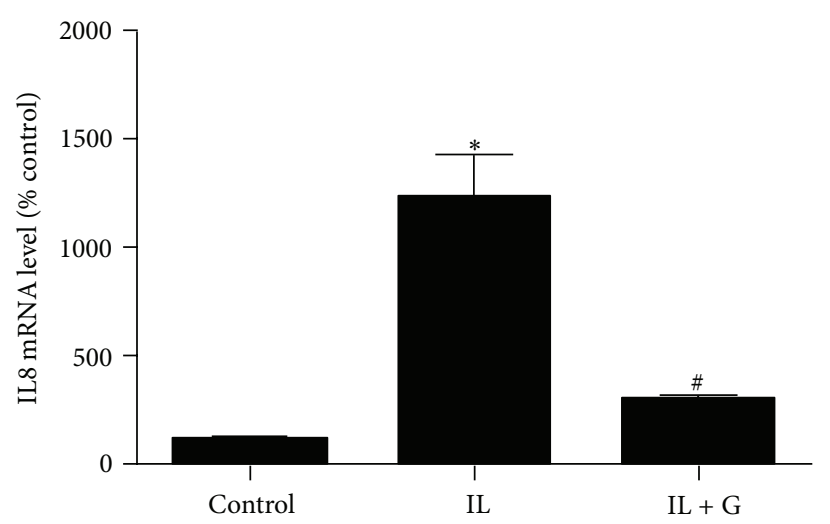

(b)

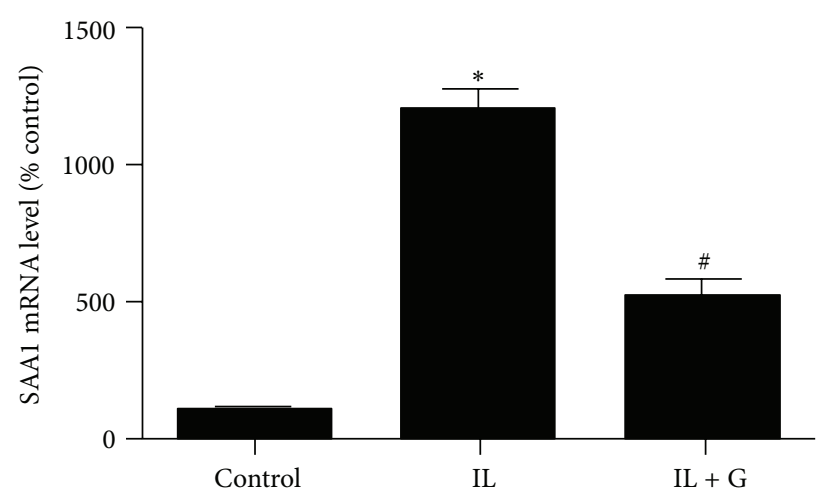

(c)

FIGURE 2: S-[6]-Gingerol decreases IL1 $\beta$-induced inflammatory factors expression in $\mathrm{HuH} 7$ cell. HuH7 cells were pretreated with $100 \mu \mathrm{M}$ $S$-[6]-gingerol (G) or DMSO (vehicle control) for $6 \mathrm{~h}$ then stimulated with IL1 $\beta$ ( $8 \mathrm{ng} / \mathrm{mL}$ ) for $3 \mathrm{~h}$. The mRNA levels of IL6 (a), IL8 (b), and SAA1 (c) were measured using RT-qPCR, normalised to B2M. Results are expressed as mean \pm SEM of 3 independent experiments, relative to DMSO controls. ${ }^{*} P<0.05$ versus DMSO vehicle control; ${ }^{\#} P<0.05$ versus ILl $\beta$ treatment.

by cobalt chloride $\left(\mathrm{CoCl}_{2}\right)$ in human skin keratinocytes [28].

Due to its proinflammatory effects, COX2 is a chief target for the treatment of inflammation. For example, the therapeutic effects of the nonsteroidal anti-inflammatory drug, aspirin, target the selective inhibition of COX2 [29]. Based on previous studies that have used IL1 $\beta$-stimulated $\mathrm{HuH} 7$ liver cells [30-32], we too established this in vitro hepatocyte cell inflammatory model to investigate the anti-inflammatory mechanisms of $S$-[6]-Gingerol. The markers of inflammation that we tested were IL6, IL8, and SAA1, all known drivers or biomarkers of liver inflammation $[33,34]$. Our results show that $S$-[6]-gingerol attenuated IL1 $\beta$-induced COX2 expression in $\mathrm{HuH7}$ cells, associated with a decrease in the expression of IL6, IL8, and SAA1. We also show that the level of inhibition achieved by $S$-[6]-gingerol for inhibition of the expression of IL6, IL8, and SAA1 was similar to that mediated by the COX2 inhibitor. Together, these data suggest that COX2 is most likely a central player in mediating the antiinflammatory effects of $S$-[6]-gingerol.
Hepatic inflammation can drive insulin resistance and the key mediator of the inflammatory response is $\mathrm{NF} \kappa \mathrm{B}$ [3]. Activated hepatic $\mathrm{NF} \kappa \mathrm{B}$ alone can drive insulin resistance as transgenic expression of the I $\kappa \mathrm{B}$ kinase $(\mathrm{IKK} \beta)$ results in overt insulin resistance in mice fed a normal chow diet [3]. By contrast, when heterozygous IKK $\beta^{+/-}$mice that express low levels of $\mathrm{NF} \kappa \mathrm{B}$ are fed a high-fat diet or are crossed with obese $o b / o b$ mice, they do not develop insulin resistance [35]. Moreover, NF- $\kappa$ B inhibition by abrogation of liver IKK activity directly protects against insulin resistance in response to a high-fat diet in mice [36]. Together, these studies suggest that the liver is a primary site of inflammatory action responsible for the development of insulin resistance and that $\mathrm{NF} \kappa \mathrm{B}$ is a central pathogenic factor underlying inflammationinduced insulin resistance. Our results show that $S$-[6]gingerol inhibited IL1 $\beta$-induced $\mathrm{NF} \kappa \mathrm{B}$ activation in $\mathrm{HuH} 7$ cells. We also show that the ability of $S$-[6]-gingerol to suppress the expression of COX2 and IL8 was the same order of magnitude induced by treatment with the $\mathrm{NF} \kappa \mathrm{B}$ inhibitor, while $S$-[6]-gingerol also significantly suppressed 


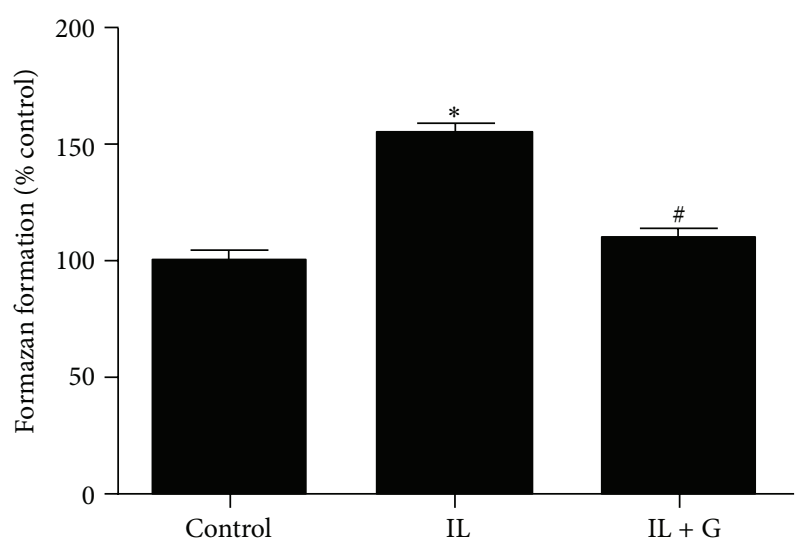

(a)

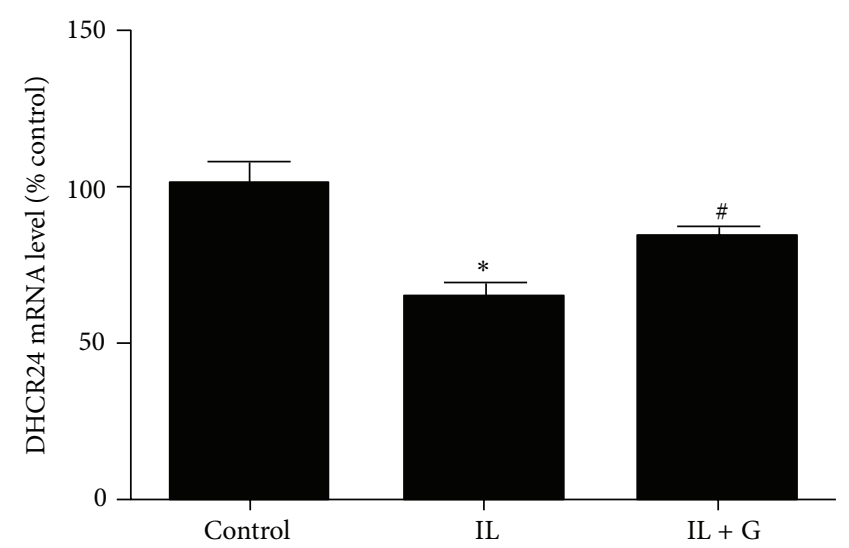

(b)

FIGURE 3: S-[6]-Gingerol inhibits IL1 $\beta$-induced oxidative stress in HuH7 cells. HuH7 cells were pretreated with $100 \mu \mathrm{M} S$-[6]-gingerol (G) or DMSO (vehicle control) for $6 \mathrm{~h}$ then stimulated with IL1 $\beta(8 \mathrm{ng} / \mathrm{mL}$ ) for $3 \mathrm{~h}$. (a) The levels of ROS generation were measured using the NBT reduction assay. The relative concentration of ROS was calculated based on the generated amount of formazan. (b) The mRNA levels of DHCR24 were measured using RT-qPCR, normalised to B2M. Results are expressed as mean \pm SEM of 3 independent experiments, relative to DMSO controls. ${ }^{*} P<0.05$ versus DMSO vehicle control; ${ }^{\#} P<0.05$ versus IL1 $\beta$ treatment.

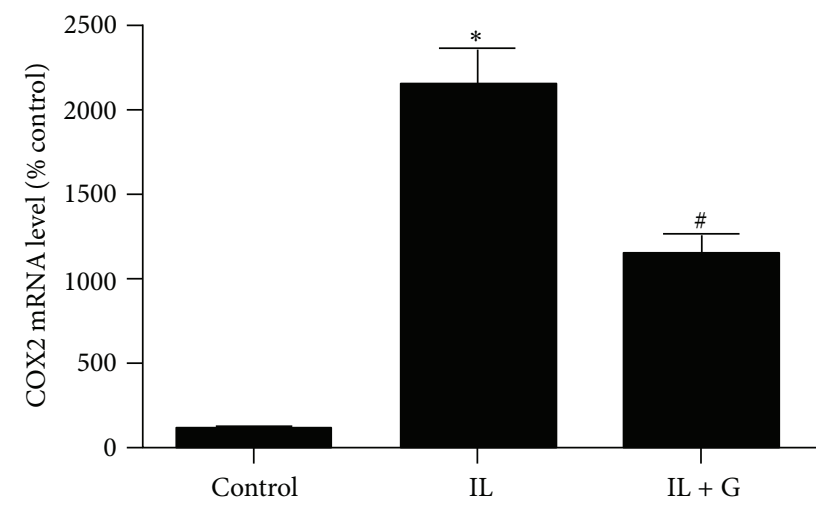

(a)

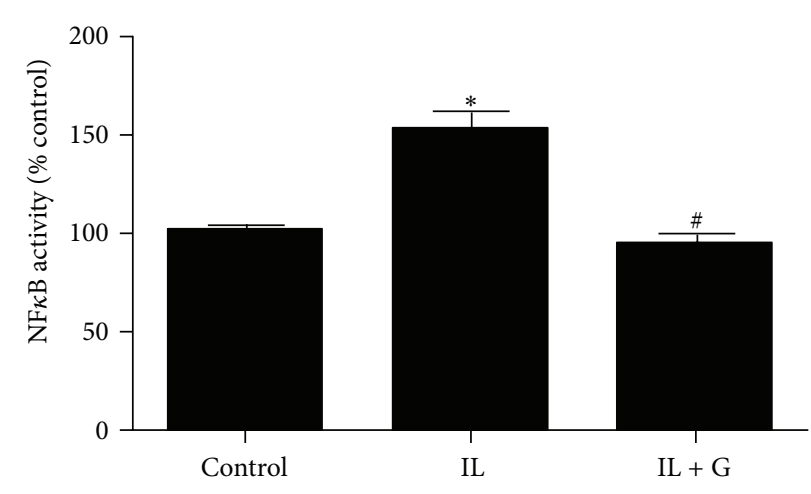

(b)

FIGURE 4: S-[6]-Gingerol suppresses IL1 $\beta$-induced COX2 expression and NFkB activity in IL1 $\beta$-stimulated HuH7 cells. (a) HuH7 cells were pretreated with $100 \mu \mathrm{M} S$-[6]-gingerol (G) or DMSO (vehicle control) for $6 \mathrm{~h}$ then stimulated with IL1 $\beta$ ( $8 \mathrm{ng} / \mathrm{mL}$ ) for $3 \mathrm{~h}$. The mRNA levels of COX2 were measured using RT-qPCR, normalised to B2M. (b) HuH7 cells were transfected with the NFkB-luciferase reporter vector. Transfectants were preincubated for $6 \mathrm{~h}$ with $100 \mu \mathrm{M}$ S-[6]-gingerol (G) or DMSO (vehicle control) and then stimulated with IL1 $\beta$ for $3 \mathrm{~h}$. Cells were then harvested and cell lysates assayed for luciferase activity. Results are expressed as mean \pm SEM of 3 independent experiments, relative to the DMSO vehicle controls. ${ }^{*} P<0.05$ versus DMSO vehicle control; ${ }^{\#} P<0.05$ versus IL1 $\beta$ treatment.

IL6 and SAA1 mRNA levels. These data suggest that NF $\kappa$ B is involved in mediating the anti-inflammatory effects of $S$ [6]-gingerol.

It is well recognized that inflammation is one manifestation of oxidative stress [37], and the pathways that generate the inflammatory factors, such as cytokines, are all induced by oxidative stress [37]. The present study shows that $S$-[6]-gingerol decreased superoxide production in IL1 $\beta$ stimulated HuH7 cells. We also show that the ability of $S$-[6]-gingerol to inhibit IL1 $\beta$-induced NFKB activation and suppress the expression of COX2 and IL6, IL8, and SAA1 paralleled the results we obtained when we treated the cells with the ROS scavenger, BHT. Our results also show that $S$ [6]-gingerol increased the expression of antioxidant enzyme, DHCR24. Given that antioxidant enzymes are able to block $\mathrm{NF} \kappa \mathrm{B}$ activation by various stimuli [38-44], our findings suggest that the anti-inflammatory effects of $S$-[6]-gingerol are mediated, at least in part, by suppressing oxidative stress.

One limitation of this study is that the mechanisms of anti-inflammatory effects of $S$-[6]-gingerol demonstrated 


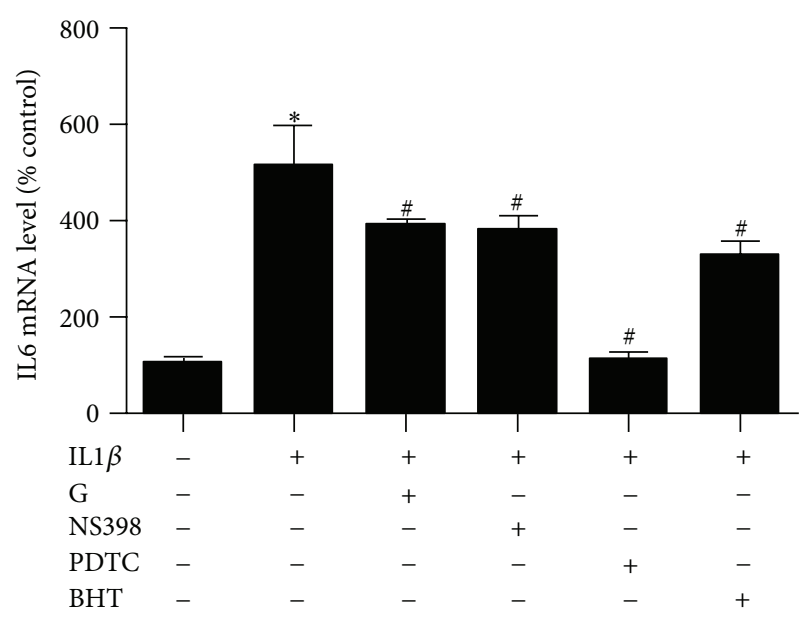

(a)

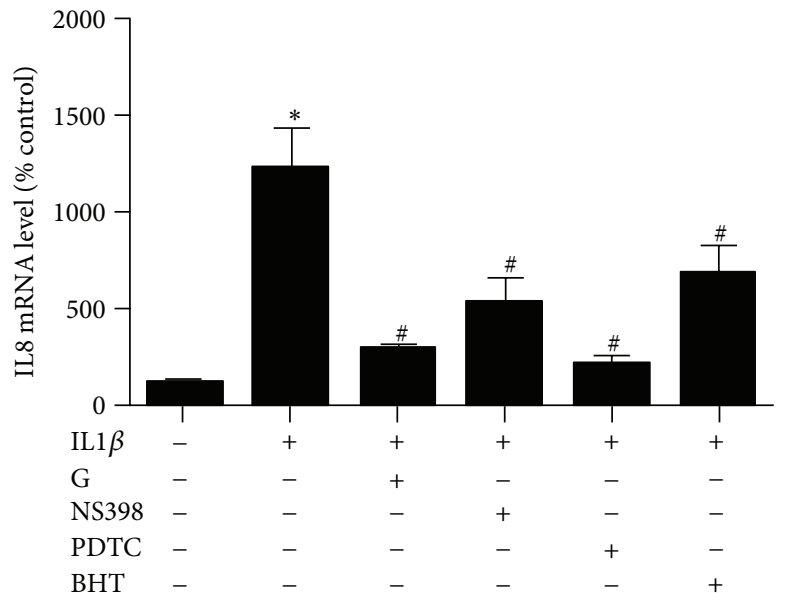

(b)

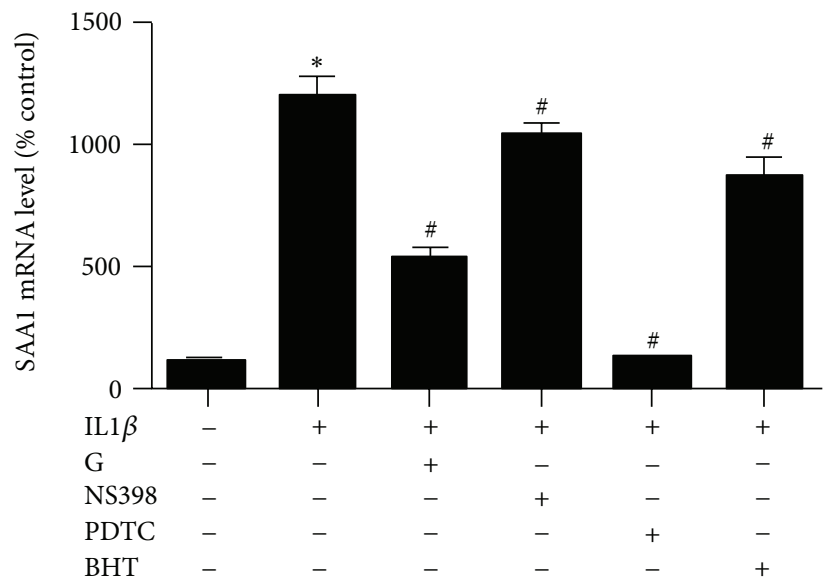

(c)

FIGURE 5: Comparison of the effects of $S$-[6]-gingerol with those of selective inhibitors on increased IL6, IL8, and SAA1 expression induced by $\operatorname{IL} 1 \beta$ in HuH7 cells. Before treatment with IL1 $\beta(8 \mathrm{ng} / \mathrm{mL})$ for $3 \mathrm{~h}$, HuH7 cells were pretreated with $100 \mu \mathrm{M} \mathrm{S}$-[6]-gingerol (G) for $6 \mathrm{~h}$, or with $100 \mu \mathrm{M}$ NS398, $50 \mu \mathrm{M}$ PDTC, or $50 \mu \mathrm{M}$ BHT for $30 \mathrm{~min}$. The mRNA levels of IL6 (a), IL8 (b), and SAA1 (c) were detected using RT-qPCR, normalized to B2M. Results are expressed as mean \pm SEM of 3 independent experiments, relative to DMSO controls. ${ }^{*} P<0.05$ versus DMSO vehicle control; ${ }^{\#} P<0.05$ versus IL1 $\beta$ treatment.

here are restricted to in vitro evidence. However, the results with the human hepatocyte cell line support previous findings in an animal model to demonstrate that the antiinflammatory effect of Zingiber officinale (ginger) occurs through the NF $\kappa B$ signalling pathway [11] and now define a mechanism of anti-inflammatory effects of $S$-[6]-gingerol through inhibition of cytokine IL1 $\beta$-induced $\mathrm{ROS} / \mathrm{NF} \kappa \mathrm{B} /$ COX2 pathway that was not possible with the animal model.

In conclusion, $S$-[6]-gingerol has been shown to inhibit IL6, IL8, and SAA1 expression in cytokine-stimulated $\mathrm{HuH7}$ cells, via suppression of COX2 expression. We have also shown that the suppression of COX2 is achieved via blockade of the $\mathrm{NF} \kappa \mathrm{B}$ signalling pathway. Finally, we have shown that $S$-[6]-gingerol blocks the $\mathrm{NF} \kappa \mathrm{B} / \mathrm{COX} 2$ pathway through suppressing the cytokine-induced oxidative stress. These results may open novel treatment options whereby $S$-[6]-gingerol could potentially protect against hepatic inflammation which underlies the pathogenesis of chronic diseases such as insulin resistance and type 2 diabetes mellitus.

\section{Conflict of Interests}

There is no conflict of interests for any author. 


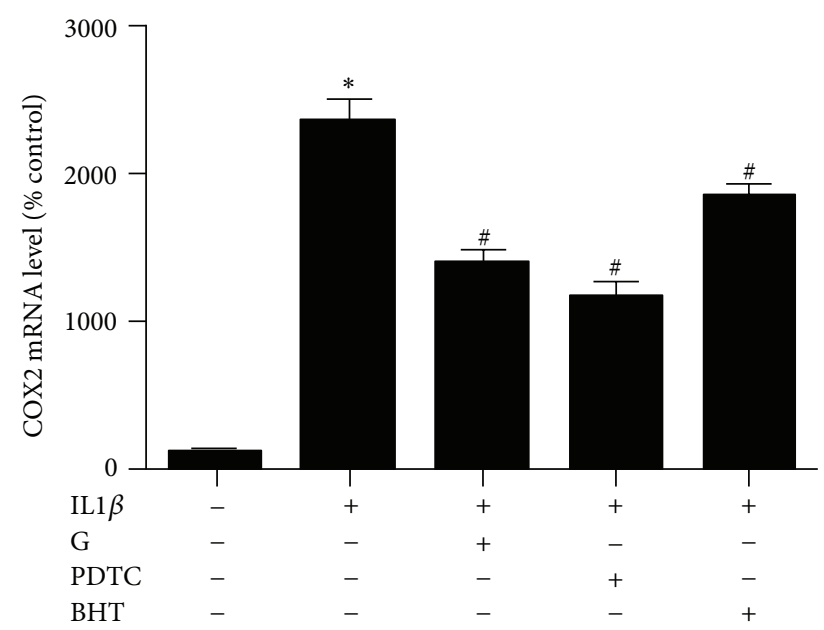

(a)

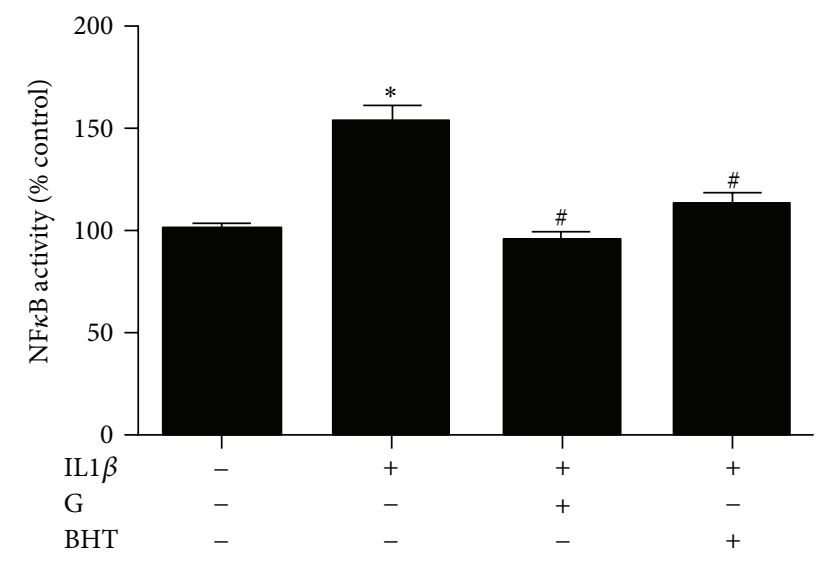

(b)

Figure 6: Comparison of the effects of $S$-[6]-gingerol with those of selective inhibitors on IL1 $\beta$-induced COX-2 expression and $\mathrm{NF} \kappa \mathrm{B}$ activity in HuH7 cells. (a) Before treatment with IL1 $\beta(8 \mathrm{ng} / \mathrm{mL})$ for $3 \mathrm{~h}, \mathrm{HuH} 7$ cells were pretreated with $100 \mu \mathrm{M}$ S-[6]-gingerol (G) for $6 \mathrm{~h}$, or with $50 \mu \mathrm{M}$ PDTC or $50 \mu \mathrm{M}$ BHT for $30 \mathrm{~min}$. The mRNA levels of COX2 were detected using RT-qPCR, normalized to B2M. (b) $\mathrm{HuH} 7$ cells were transfected with the $\mathrm{NF} \kappa \mathrm{B}$-luciferase reporter vector. Before treatment with IL1 $\beta(8 \mathrm{ng} / \mathrm{mL})$ for $3 \mathrm{~h}$, transfected $\mathrm{HuH} 7$ cells were pretreated with $100 \mu \mathrm{M} \mathrm{S}$-[6]-gingerol (G) for $6 \mathrm{~h}$, or with $50 \mu \mathrm{M}$ BHT for $30 \mathrm{~min}$. Cells were then harvested and cell lysates assayed for luciferase activity. Results are expressed as mean \pm SEM of 3 independent experiments, relative to the DMSO vehicle controls. ${ }^{*} P<0.05$ versus DMSO vehicle control; ${ }^{\#} P<0.05$ versus $\operatorname{IL} 1 \beta$.

\section{References}

[1] G. S. Hotamisligil, "Inflammation and metabolic disorders," Nature, vol. 444, no. 7121, pp. 860-867, 2006.

[2] P. Marceau, S. Biron, F.-S. Hould et al., "Liver pathology and the metabolic syndrome X in severe obesity," Journal of Clinical Endocrinology and Metabolism, vol. 84, no. 5, pp. 1513-1517, 1999.

[3] D. Cai, M. Yuan, D. F. Frantz et al., "Local and systemic insulin resistance resulting from hepatic activation of IKK-beta and NF-kappaB," Nature Medicine, vol. 11, no. 2, pp. 183-190, 2005.
[4] S. Ghosh, M. J. May, and E. B. Kopp, "NF- $\kappa$ B and rel proteins: evolutionarily conserved mediators of immune responses," Annual Review of Immunology, vol. 16, pp. 225-260, 1998.

[5] J. W. Christman, L. H. Lancaster, and T. S. Blackwell, "Nuclear factor $\kappa \mathrm{B}$ : a pivotal role in the systemic inflammatory response syndrome and new target for therapy," Intensive Care Medicine, vol. 24, no. 11, pp. 1131-1138, 1998.

[6] S. A. Abd-El-Aleem, M. W. J. Ferguson, I. Appleton, A. Bhowmick, C. N. McCollum, and G. W. Ireland, "Expression of cyclooxytenase isoforms in normal human skin and chronic venous ulcers," Journal of Pathology, vol. 195, no. 5, pp. 616-623, 2001.

[7] M. Afzal, D. Al-Hadidi, M. Menon, J. Pesek, and M. S. I. Dhami, "Ginger: an ethnomedical, chemical and pharmacological review," Drug Metabolism and Drug Interactions, vol. 18, no. 3-4, pp. 159-190, 2001.

[8] R. Grzanna, L. Lindmark, and C. G. Frondoza, "Gingeran herbal medicinal product with broad anti-inflammatory actions," Journal of Medicinal Food, vol. 8, no. 2, pp. 125-132, 2005.

[9] H. W. Jung, C.-H. Yoon, K. M. Park, H. S. Han, and Y.-K. Park, "Hexane fraction of Zingiberis Rhizoma Crudus extract inhibits the production of nitric oxide and proinflammatory cytokines in LPS-stimulated BV2 microglial cells via the NFkappaB pathway," Food and Chemical Toxicology, vol. 47, no. 6, pp. 1190-1197, 2009.

[10] C. G. Frondoza, A. Sohrabi, A. Polotsky, P. V. Phan, D. S. Hungerford, and L. Lindmark, "An in vitro screening assay for inhibitors of proinflammatory mediators in herbal extracts using human synoviocyte cultures," In Vitro Cellular \& Developmental Biology, vol. 40, no. 3-4, pp. 95-101, 2004.

[11] X.-H. Li, K. C.-Y. McGrath, S. Nammi, A. K. Heather, and B. D. Roufogalis, "Attenuation of liver pro-inflammatory responses by Zingiber officinale via inhibition of NF-kappa B activation in high-fat diet-fed rats," Basic and Clinical Pharmacology and Toxicology, vol. 110, no. 3, pp. 238-244, 2012.

[12] A. A. Oyagbemi, A. B. Saba, and O. I. Azeez, "Molecular targets of [6]-gingerol: its potential roles in cancer chemoprevention," BioFactors, vol. 36, no. 3, pp. 169-178, 2010.

[13] S. Tripathi, K. G. Maier, D. Bruch, and D. S. Kittur, "Effect of 6gingerol on pro-inflammatory cytokine production and costimulatory molecule expression in murine peritoneal macrophages," Journal of Surgical Research, vol. 138, no. 2, pp. 209-213, 2007.

[14] C. Lee, G. H. Park, C.-Y. Kim, and J.-H. Jang, "[6]-Gingerol attenuates $\beta$-amyloid-induced oxidative cell death via fortifying cellular antioxidant defense system," Food and Chemical Toxicology, vol. 49, no. 6, pp. 1261-1269, 2011.

[15] Y. Li, V. H. Tran, C. C. Duke, and B. D. Roufogalis, “Gingerols of Zingiber officinale enhance glucose uptake by increasing cell surface GLUT4 in cultured L6 myotubes," Planta Medica, vol. 78, no. 14, pp. 1549-1555, 2012.

[16] A. K. Death, K. C. Y. McGrath, M. A. Sader et al., "Dihydrotestosterone promotes vascular cell adhesion molecule-1 expression in male human endothelial cells via a nuclear factor$\kappa \mathrm{B}$-dependent pathway," Endocrinology, vol. 145, no. 4, pp. 18891897, 2004.

[17] S. A. Bustin, "Absolute quantification of mrna using real-time reverse transcription polymerase chain reaction assays," Journal of Molecular Endocrinology, vol. 25, no. 2, pp. 169-193, 2000.

[18] K. C. Y. McGrath, X. H. Li, R. Puranik et al., "Role of $3 \beta$ hydroxysteroid- $\Delta 24$ reductase in mediating antiinflammatory 
effects of high-density lipoproteins in endothelial cells," Arteriosclerosis, Thrombosis, and Vascular Biology, vol. 29, no. 6, pp. 877-882, 2009.

[19] G. D. Anderson, S. D. Hauser, K. L. McGarity, M. E. Bremer, P. C. Isakson, and S. A. Gregory, "Selective inhibition of cyclooxygenase (COX)-2 reverses inflammation and expression of COX2 and interleukin 6 in rat adjuvant arthritis," The Journal of Clinical Investigation, vol. 97, no. 11, pp. 2672-2679, 1996.

[20] J. P. Portanova, Y. Zhang, G. D. Anderson et al., "Selective neutralization of prostaglandin E2 blocks inflammation, hyperalgesia, and interleukin 6 production in vivo," Journal of Experimental Medicine, vol. 184, no. 3, pp. 883-891, 1996.

[21] K. Seibert, Y. Zhang, K. Leahy et al., "Pharmacological and biochemical demonstration of the role of cyclooxygenase 2 in inflammation and pain," Proceedings of the National Academy of Sciences of the United States of America, vol. 91, no. 25, pp. 1201312017, 1994.

[22] H. K. Cho, K. J. Cheong, H. Y. Kim, and J. Cheong, "Endoplasmic reticulum stress induced by hepatitis $\mathrm{B}$ virus $\mathrm{X}$ protein enhances cyclo-oxygenase 2 expression via activating transcription factor 4," Biochemical Journal, vol. 435, no. 2, pp. 431-439, 2011.

[23] C. S. Williams, M. Mann, and R. N. DuBois, "The role of cyclooxygenases in inflammation, cancer, and development," Oncogene, vol. 18, no. 55, pp. 7908-7916, 1999.

[24] N. S. Buttar and K. K. Wang, "The "aspirin" of the new millennium: cyclooxygenase-2 inhibitors," Mayo Clinic Proceedings, vol. 75, no. 10, pp. 1027-1038, 2000.

[25] E. Fosslien, "Biochemistry of cyclooxygenase (COX)-2 inhibitors and molecular pathology of COX-2 in neoplasia," Critical Reviews in Clinical Laboratory Sciences, vol. 37, no. 5, pp. 431$502,2000$.

[26] S. L. Tilley, T. M. Coffman, and B. H. Koller, "Mixed messages: modulation of inflammation and immune responses by prostaglandins and thromboxanes," The Journal of Clinical Investigation, vol. 108, no. 1, pp. 15-23, 2001.

[27] S. Tsutakawa, D. Kobayashi, M. Kusama, T. Moriya, and N. Nakahata, "Nicotine enhances skin necrosis and expression of inflammatory mediators in a rat pressure ulcer model," British Journal of Dermatology, vol. 161, no. 5, pp. 1020-1027, 2009.

[28] C. Yang, Z. Yang, M. Zhang et al., "Hydrogen sulfide protects against chemical hypoxia-induced cytotoxicity and inflammation in hacat cells through inhibition of ROS/NF- $\kappa \mathrm{B} / \mathrm{COX}-2$ pathway," PLoS ONE, vol. 6, no. 7, Article ID e21971, 2011.

[29] J. Vane, "Towards a better aspirin," Nature, vol. 367, no. 6460, pp. 215-216, 1994.

[30] P.-C. Tseng, H.-C. Hsu, D. Janmanchi et al., "Helioxanthin inhibits interleukin- $1 \beta$-induced MIP- $1 \beta$ production by reduction of $c$-jun expression and binding of the $c$-jun/CREB1 complex to the AP-1/CRE site of the MIP-1 $\beta$ promoter in Huh7 cells," Biochemical Pharmacology, vol. 76, no. 9, pp. 1121-1133, 2008.

[31] R. Kleemann, L. Verschuren, B.-J. De Rooij et al., "Evidence for anti-inflammatory activity of statins and PPAR $\alpha$ activators in human C-reactive protein transgenic mice in vivo and in cultured human hepatocytes in vitro," Blood, vol. 103, no. 11, pp. 4188-4194, 2004.

[32] R. Kleemann, P. P. Gervois, L. Verschuren, B. Staels, H. M. G. Princen, and T. Kooistra, "Fibrates down-regulate IL-1stimulated C-reactive protein gene expression in hepatocytes by reducing nuclear $\mathrm{p} 50-\mathrm{NF} \kappa \mathrm{B}-\mathrm{C} / \mathrm{EBP}-\beta$ complex formation," Blood, vol. 101, no. 2, pp. 545-551, 2003.
[33] S. F. El-Tayeh, T. D. Hussein, M. E. El-Houseini, M. A. Amer, M. El-Sherbini, and W. M. Elshemey, "Serological biomarkers of hepatocellular carcinoma in Egyptian patients," Disease Markers, vol. 32, no. 4, pp. 255-263, 2012.

[34] T. A. Pearson, G. A. Mensah, R. W. Alexander et al., "Markers of inflammation and cardiovascular disease: application to clinical and public health practice: a statement for healthcare professionals from the centers for disease control and prevention and the American Heart Association," Circulation, vol. 107, no. 3, pp. 499-511, 2003.

[35] G. S. Hotamisligil, "Inflammatory pathways and insulin action," International Journal of Obesity, vol. 27, supplement 3, pp. S53S55, 2003.

[36] M. C. Arkan, A. L. Hevener, F. R. Greten et al., "IKK-beta links inflammation to obesity-induced insulin resistance," Nature Medicine, vol. 11, no. 2, pp. 191-198, 2005.

[37] K. A. Roebuck, "Oxidant stress regulation of IL-8 and ICAM-1 gene expression: differential activation and binding of the transcription factors AP-1 and NF-kappaB (Review)," International Journal of Molecular Medicine, vol. 4, no. 3, pp. 223-230, 1999.

[38] S. W. Kang, H. Z. Chae, M. S. Seo, K. Kim, I. C. Baines, and S. G. Rhee, "Mammalian peroxiredoxin isoforms can reduce hydrogen peroxide generatedin response to growth factors and tumor necrosis factor- $\alpha$," The Journal of Biological Chemistry, vol. 273, no. 11, pp. 6297-6302, 1998.

[39] H. Schenk, M. Klein, W. Erdbrügger, W. Dröge, and K. SchulzeOsthoff, "Distinct effects of thioredoxin and antioxidants on the activation of transcription factors NF-kappa B and AP-1," Proceedings of the National Academy of Sciences of the United States of America, vol. 91, no. 5, pp. 1672-1676, 1994.

[40] R. Brigelius-Flohé, B. Friedrichs, S. Maurer, M. Schultz, and R. Streicher, "Interleukin-1-induced nuclear factor $\kappa \mathrm{B}$ activation is inhibited by overexpression of phospholipid hydroperoxide glutathione peroxidase in a human endothelial cell line," Biochemical Journal, vol. 328, no. 1, pp. 199-203, 1997.

[41] S. K. Manna, H. J. Zhang, T. Yan, L. W. Oberley, and B. B. Aggarwal, "Overexpression of manganese superoxide dismutase suppresses tumor necrosis factor-induced apoptosis and activation of nuclear transcription factor- $\kappa \mathrm{B}$ and activated protein-1," The Journal of Biological Chemistry, vol. 273, no. 21, pp. 13245-13254, 1998.

[42] C. Kretz-Remy, P. Mehlen, M.-E. Mirault, and A.-P. Arrigo, "Inhibition of $\mathrm{I} \kappa \mathrm{B}-\alpha$ phosphorylation and degradation and subsequent NF- $\kappa$ B activation by glutathione peroxidase overexpression," Journal of Cell Biology, vol. 133, no. 5, pp. 1083-1093, 1996.

[43] R. Lee, P. Beauparlant, H. Elford, P. Ponka, and J. Hiscott, "Selective inhibition of $\mathrm{I} \kappa \mathrm{B} \alpha$ phosphorylation and HIV-1 LTRdirected gene expression by novel antioxidant compounds," Virology, vol. 234, no. 2, pp. 277-290, 1997.

[44] X. Lu, F. Kambe, X. Cao et al., " $3 \beta$-hydroxysteroid- $\Delta 24$ reductase is a hydrogen peroxide scavenger, protecting cells from oxidative stress-induced apoptosis," Endocrinology, vol. 149, no. 7, pp. 3267-3273, 2008. 


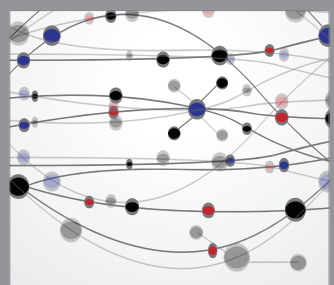

The Scientific World Journal
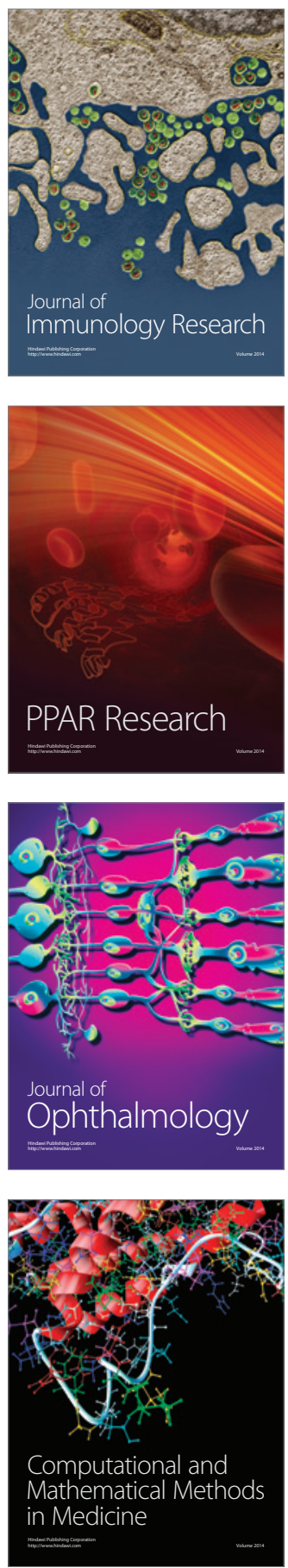

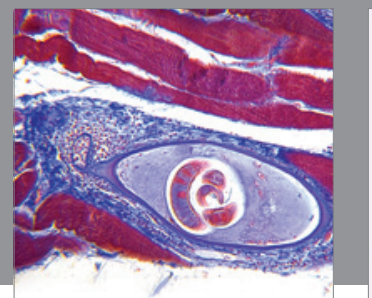

Gastroenterology

Research and Practice
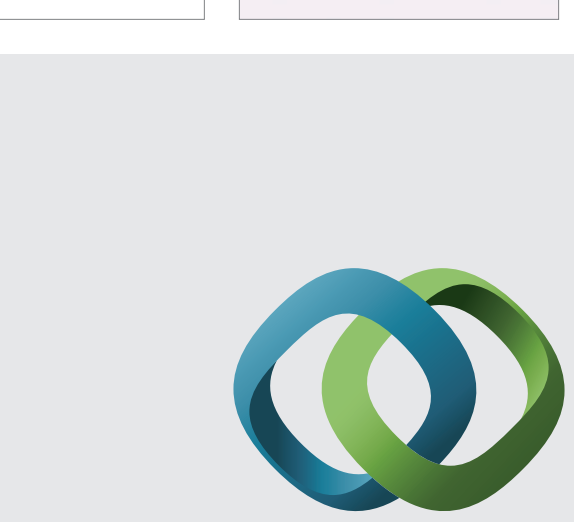

\section{Hindawi}

Submit your manuscripts at

http://www.hindawi.com
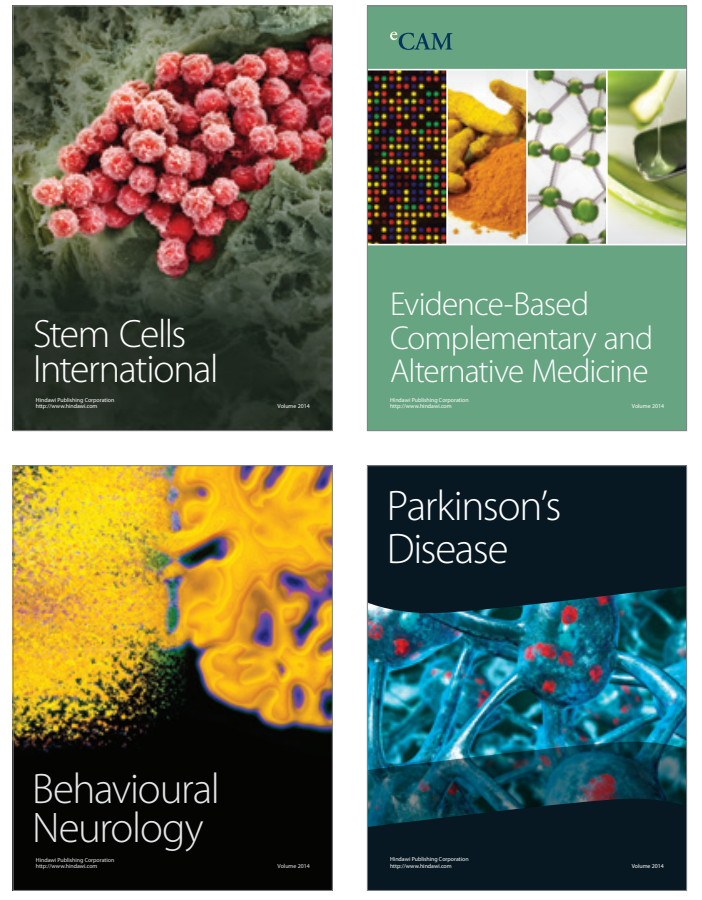
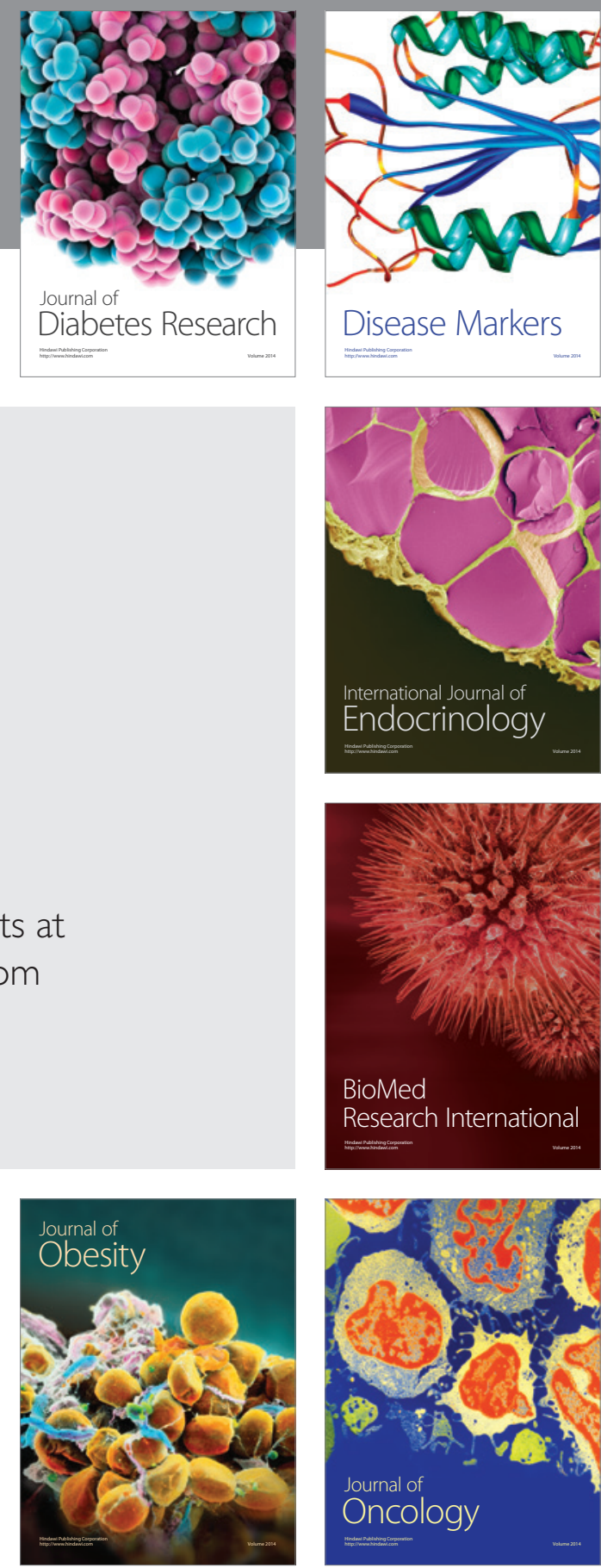

Disease Markers
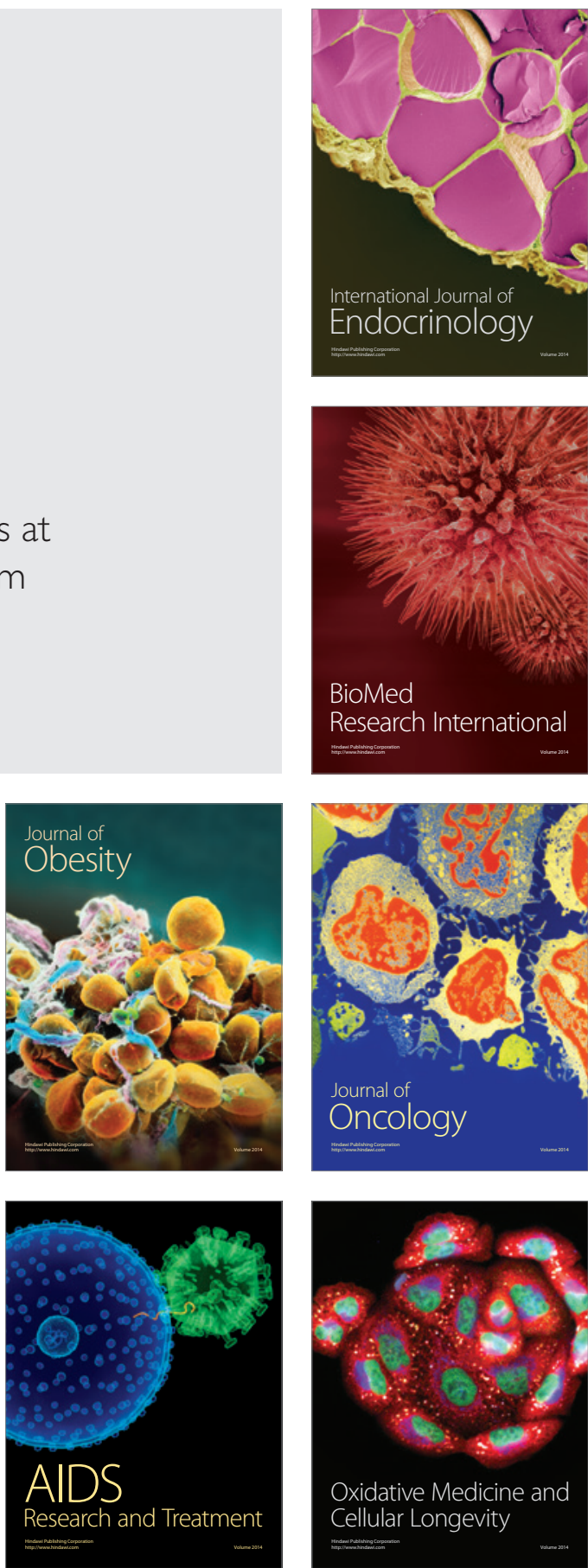